\title{
Effects of Moisture and Temperature on Germination of Idaho Fescue
}

\author{
PAUL DOESCHER, RICHARD MILLER, AND ALMA WINWARD
}

\begin{abstract}
Germination response to varying temperatures and water stress levels during a 30-day incubation period was observed in 4 eastern Oregon collections of Festuca idahoensis Elmer. Seeds were selected from the following habitat types: Artemisia tridentata ssp. wyomingensis/Festuca idahoensis (ARTRV/FEID), Pinus ponderosa Dougl./Festuca idahoensis (PIPO/FEID). One stand of each habitat type was sampled, except for the ARTRV/FEID habitat type where seed was selected from both a high and low elevation plant community. The low elevation stand will be designated ARTRV"L"/FEID. Incubation temperature treatments were held constant $\left( \pm 2^{\circ} \mathrm{C}\right)$ and ranged in $5^{\circ} \mathrm{C}$ increments from $5^{\circ}$ $\mathrm{C}$ to $35^{\circ} \mathrm{C}$. At 15, 20, and $25^{\circ} \mathrm{C}$, water stresses of $0.0 \mathrm{MPa},-0.6$ $\mathrm{MPa}$, and $-0.9 \mathrm{MPa}$ were depressed using polyethylene glycol 6000. Collectively, maximum total germination for all collections occurred at and above $10^{\circ} \mathrm{C}$ and below $30^{\circ} \mathrm{C}$. Germination percentages for seeds from ARTRW/FEID, ARTRV/FEID and PIPO/FEID habitat types at $10^{\circ} \mathrm{C}$ were $93.0,97.0,91.9$, and $88.8 \%$, respectively. Maximum germination rates for all collections occurred between $20-25^{\circ} \mathrm{C}$. As water stress decreased and temperature increased, both germination amount and rate for the 4 collections declined. Seeds of Idaho fescue collected from sagebrush habitat types maintained higher germination amounts and faster germination rates over wider temperature and moisture stress regime than did seeds selected from the PIPO/FEID site.
\end{abstract}

Seed production and germination are important for the survival of plant species given the variable conditions of most natural ecosystems. Parameters which influence the adaptability and regeneration success of a species' population include moisture stress and temperature (Eddleman 1979). Because moisture and temperature vary across environmental gradients, selective forces have probably resulted in the development of ecotypes sensitive to the climatic regimes of a given area (Turreson 1922).

Reports examining germination characteristics of native species suggest ecotypic differences in response to variable incubation environments (Chouduri 1968, Capon et al. 1978, Lindauer and Quinn 1977, Workman and West 1967, Young and Evans 1981). However, relatively little research has examined germination response from seed collected along environmental gradients in local geographic areas.

\footnotetext{
Authors are assistant professor, Rangeland Resources Department, Oregon State University, Corvallis 97331; associate professor, Eastern Oregon Agricultural Research Center, Star Rt. 1-4.5t Hwy. 205, Burns, Oregon 97720; and regional forest ecologist, Regional Office, U.S. Forest Service, Fed. Office Building, 324-25th Street, Ogden, Utah 84401 .

This research was a cooperative effort and jointly supported by the USDA, Agricultural Research Service and Eastern Oregon Agricultural Research Center, Squaw Butte Station, Agricultural Experiment Station.

Tech. Paper No. 7332, Oregon Agricultural Experiment Station.

Manuscript accepted December 19,1984.
}

This research was designed to evaluate germination response of 4 eastern Oregon seed collections of Idaho fescue to varying conditions of temperature and substrate water stress. Idaho fescue is a cool-season perennial bunchgrass indigenous to communitics dominated by big sagebrush (Artemisia tridentata Nutt.) and ponderosa pine (Pinus ponderosa Dougl.). Optimum germination temperatures for Idaho fescue have been reported to be between 15 to ${ }^{\circ} \mathrm{C}$ (Young et al. 1981, Stocker 1975).

\section{Materials and Methods}

Seed Collection and Processing

Idaho fescue seeds were collected from the following habitat types: Artemisia tridentata ssp. wyomingensis/Festuca idahoensis (ARTRW/FEID) (Doescher 1983), Artemisia tridentata ssp. vaseyana/Festuca idahoensis (ARTRV/FEID) (Winward 1970) and Pinus ponderosa/ Festuca idahoensis (PIPO/FEID) (Franklin and Dyrness 1973). One stand of each habitat type was sampled, except for the ARTRV/FEID habitat type where seed was collected from both a high and low elevation plant community. The low elevation stand occurred on coarse pumice soils. For purposes of this discussion, this site will be referred to as the ARTRV"L"/ FEID habitat type.

All habitat types were chosen in the same general geographic region (Table 1). It was assumed that ARTRW/FEID habitat type was the most xeric, the PIPO habitat type the most mesic and the ARTRV"L"/FEID and ARTRV/FEID habitat type intermediate in moisture relations. All sites had a dominant understory of Idaho fescue.

Seeds of Idaho fescue were collected by hand stripping at various times during the 1980 growing season and cleaned by hand threshing and screening to remove caryopses from chaff. Seeds were stored at room temperatures. In order to standardize seed weight during experimentation, only heavy seeds were used in germination trials. Unfilled and light seeds were removed with a seed blower, with blower settings held constant for each seed lot. Abnormally developed embryos observed on a light table were not included in the germination experiments. Seeds used in experimentation were collected during seed shatter as test of seed viability with tetrazolim chloride indicated better stress germination from seeds collected during this phenological period. Seeds approximately 8 months of age were used in the germination trials.

\section{Experimental Procedure}

Seeds were concurrently germinated in environmental chambers under seven constant temperatures $\left(5,10,15,20,25,30\right.$, and $\left.35^{\circ} \mathrm{C}\right)$ and six combinations of temperature and water stress $\left(15^{\circ} \mathrm{C} / 0.0\right.$ $\mathrm{MPA}, 15^{\circ} \mathrm{C} /-0.6 \mathrm{MPa}, 15^{\circ} \mathrm{C} /-0.9 \mathrm{MPa}, 20^{\circ} \mathrm{C} / 0.0 \mathrm{MPa}, 20^{\circ} \mathrm{C} /-0.6$ 
Table 1. Habitat types and site characteristics of four eastern Oregon seed lots of Festuca idahoensis.

\begin{tabular}{|c|c|c|c|c|c|}
\hline Habitat type & Abbreviation & $\begin{array}{l}\text { Elevation } \\
\text { (meters) }\end{array}$ & Site location & Soil description & $\begin{array}{l}\text { Texture of } \\
\text { surface soil }\end{array}$ \\
\hline $\begin{array}{l}\text { Artemisia tridentata ssp. wyomingensis/ } \\
\text { Festuca idahoensis }\end{array}$ & ARTRW/FEID & 1350 & $\begin{array}{c}\text { SW1/4NW1/4S33 } \\
\text { R2IS, R21E } \\
\text { Near Hampton, OR }\end{array}$ & $\begin{array}{c}\text { Xerollic } \\
\text { Durargid }\end{array}$ & Loamy sand \\
\hline $\begin{array}{l}\text { Artemisia tridentata ssp. vaseyana " } L \text { " } \\
\text { Festuca idahoensis }\end{array}$ & ARTRV“P”/FEID & 1400 & $\begin{array}{c}\text { SE1/4NE1/4S20 } \\
\text { R20S, R 18F } \\
\text { Near Brothers, OR }\end{array}$ & $\begin{array}{l}\text { Xerollic } \\
\text { Durargid }\end{array}$ & Sandy loam \\
\hline $\begin{array}{l}\text { Artemisia tridentata ssp. vaseyana } \\
\text { Festuca idahoensis }\end{array}$ & ARTRV/FEID & 1700 & $\begin{array}{c}\text { SE } 1 / 4 \mathrm{NW} 1 / 44 \mathrm{~S} 12 \\
\text { T21S, R20E } \\
\text { Near Hampton, OR }\end{array}$ & $\begin{array}{l}\text { Argic } \\
\text { Cryboroll }\end{array}$ & Sandy loam \\
\hline Pinus ponderosa/Festuca idahoensis & PIPO/FEID & 1750 & $\begin{array}{c}\text { NW1 } / 4 \text { SE } 1 / 4 \text { S } 22 \\
\text { T20S,R } 15 E \\
\text { Near Millican, OR }\end{array}$ & $\begin{array}{l}\text { Typic } \\
\text { Cryboroll }\end{array}$ & Loam \\
\hline
\end{tabular}

$\mathrm{MPa}, 20^{\circ} \mathrm{C} /-0.9 \mathrm{MPa}, 25^{\circ} \mathrm{C} /-0.0 \mathrm{MPa}, 25^{\circ} \mathrm{C} /-0.6 \mathrm{MPa}, 25^{\circ} \mathrm{C} /-0.9$ $\mathrm{MPa}$ ). The water stress of each solution was depressed using polyethylene glycol (PEG) MW 6000 and specific values were computed using the procedures outlined by Michel and Kaufmann (1973).

Four replications of 25 seeds were used for each treatment/population combination. Seeds were imbibed on cellulose pads in petri dishes with either distilled water or PEG 6000 solutions added in sufficient quantities to saturate the germination medium but cause puddling only on the bottom of the petri dish. Petri dishes were placed 4 deep on a metal tray containing a single layer of saturated cellulose on the bottom. One tray was used for each water stres$\mathrm{s} /$ temperature combination. Trays were enclosed by 2 black plastic bags in order to maintain dark germination conditions and a high humidity environment during the germination trial. Trays were randomly placed within growth chambers and rotated daily. A seed was considered germinated when both radicle and shoot had elongated at least $3 \mathrm{~mm}$. Ungerminated seeds were tested for filled caryopses by backlighting. Germination counts were converted into percentages for statistical interpretation.

\section{Data Analysis}

Germination treatments were tested $(=.05)$ using a factorial Analysis of Variance. Total germination percentages were transformed using an arcsine square-root transformation in order to make the statistical distribution more normal (Sokal and Rohlf 1969). Two values were computed to evaluate germination rate.

1. Maquire's (1962) Coefficient of Rate of Germination (CRG)-a value which considers speed of germination as well as total number of seeds which germinate on a given day. CRGs were derived from percent germination.

2. Days to $50 \%$ of Total Germination-an indication germination rate independent of total number of seeds which germinate. The smaller the value, the greater the germination rate.

Differences between collections, temperatures, and water stresses were assessed using Tukey's-w procedure $(\alpha=.05)$ (Steel and Torrie 1980). When significant interactions existed between main effect means, only those judged to have ecological significance were interpreted.

\section{Results}

\section{Germination Response to Constant Temperatures}

Characterization of germination properties over temperatures of $5,10,15,20,25$, and $30^{\circ} \mathrm{C}$ indicated a differential response within the 4 Idaho fescue collections. Germination did not occur for any of the collections at $35^{\circ} \mathrm{C}$. A collection $\times$ temperature interaction occurred for both mean total percent germination and mean CRG.
All collections germinated well at $10^{\circ} \mathrm{C}$ (Table 2). However, seed germination was maintained at significantly higher percentages over a wider temperature range for collections from the sagebrush habitat types than was evident for seeds collected from

Table 2. Two-way interactions means for total percent germination at six constant temperatures. Error mean square value of the transformed data from analysis of variance was $\mathbf{4 2 . 2 9}$.

\begin{tabular}{lllllll}
\hline & \multicolumn{6}{c}{ Temperature C } \\
\cline { 2 - 6 } Collection & \multicolumn{1}{c}{5} & 10 & 15 & 20 & 25 & 30 \\
\hline & & \multicolumn{1}{c}{$\%$} & & & \\
ARTRW/FEID & $69 \mathrm{ab} *$ & $93 \mathrm{ab}$ & $88 \mathrm{a}$ & $95 \mathrm{a}$ & $87 \mathrm{a}$ & $75 \mathrm{a}$ \\
ARTRV"L"/FEID & $62 \mathrm{bd}$ & $97 \mathrm{a}$ & $88 \mathrm{a}$ & $88 \mathrm{ab}$ & $90 \mathrm{a}$ & $65 \mathrm{ab}$ \\
ARTRV/FEID & $82 \mathrm{a}$ & $92 \mathrm{ab}$ & $94 \mathrm{a}$ & $78 \mathrm{bd}$ & $91 \mathrm{a}$ & $72 \mathrm{ab}$ \\
PIPO/FEID & $47 \mathrm{~d}$ & $89 \mathrm{~b}$ & $65 \mathrm{~b}$ & $71 \mathrm{~d}$ & $61 \mathrm{~b}$ & $52 \mathrm{~b}$ \\
\hline
\end{tabular}

* Similar letters denote non-significant differences between collections at a particular temperature level $(\alpha=.05)$, using Tukey's w-procedure.

the PIPO/FEID habitat type. Optimum germination percentages declined on either side of the $10^{\circ} \mathrm{C}$ temperature for the PIPO/FEID selection. Collections from the ARTRW/FEID and ARTRV"L"/FEID sites were judged not different at all temperature treatments. Collection ARTRV/FEID differed from collection ARTRV"L"/FEID and ARTRW/FEID at 5 and $20^{\circ} \mathrm{C}$, respectively but never differed from both collections at the same temperatures.

Maximum germination rates for all collections were exhibited at $20-25^{\circ} \mathrm{C}$ (Table 3). At temperatures above $10^{\circ} \mathrm{C}$, mean $\mathrm{CRG}$

Table 3. Two-way interaction means for Coefricient of Rate of Germination (CRG) at six constant temperatures. Error mean square value from analysis of variance was 1.34 .

\begin{tabular}{lcccccc}
\hline \hline & \multicolumn{7}{c}{ Temperature C } \\
\cline { 2 - 7 } Collection & 5 & 10 & 15 & 20 & 25 & 30 \\
\hline & & \multicolumn{7}{c}{ CRG } & & & \\
ARTRW/FEID & $2.7 \mathrm{a}^{*}$ & $8.9 \mathrm{a}$ & $11.2 \mathrm{ab}$ & $14.5 \mathrm{a}$ & $13.4 \mathrm{a}$ & $9.5 \mathrm{a}$ \\
ARTRV“L"/FEID & $2.4 \mathrm{a}$ & $9.7 \mathrm{a}$ & $10.8 \mathrm{a}$ & $14.5 \mathrm{a}$ & $14.4 \mathrm{a}$ & $8.8 \mathrm{a}$ \\
ARTRV/FEID & $3.4 \mathrm{a}$ & $9.2 \mathrm{a}$ & $13.1 \mathrm{~b}$ & $12.6 \mathrm{a}$ & $15.5 \mathrm{a}$ & $9.3 \mathrm{a}$ \\
PIPO/FEID & $1.8 \mathrm{a}$ & $7.9 \mathrm{a}$ & $6.7 \mathrm{c}$ & $9.4 \mathrm{~b}$ & $8.2 \mathrm{~b}$ & $5.6 \mathrm{~b}$ \\
\hline
\end{tabular}

* Similar letters denote non-significant differences between collections at a particular temperature level $(\alpha=.05)$ using Tukey's w-procedure

values were greater for collections from sagebrush sites in comparison to seeds from the pine-dominated community. Main effect means for days to $50 \%$ germination for the ARTRW/FEID, ARTRV“L"/FEID, ARTRV/FEID and PIPO/FEID collections were $10.5,10.6,10.2$, and 12.1 , respectively. The PIPO/FEID collection exhibited a slower response for days to $50 \%$ germination 


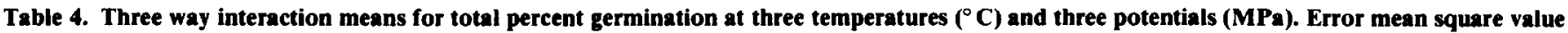
of the transformed data was $\mathbf{4 1 . 9 2}$.

\begin{tabular}{|c|c|c|c|c|c|c|c|c|c|}
\hline \multirow[b]{3}{*}{ Water Stress } & \multicolumn{9}{|c|}{ Temperature } \\
\hline & \multicolumn{3}{|c|}{15} & \multicolumn{3}{|c|}{20} & \multirow[b]{2}{*}{0} & \multicolumn{2}{|l|}{25} \\
\hline & 0 & -.6 & -.9 & 0 & -.6 & -.9 & & -.6 & -.9 \\
\hline \multicolumn{5}{|l|}{ Collection } & \multicolumn{3}{|c|}{$\%$ Germination } & & \\
\hline ARTRW/FEID & $88 \mathrm{a}$ & $92 a$ & $82 a$ & $95 \mathbf{a}$ & $89 \mathrm{ab}$ & $73 a$ & $87 a$ & $54 a b$ & $31 \mathbf{a}$ \\
\hline ARTRV“L"/FEID & $88 a$ & $95 \mathrm{a}$ & $86 a$ & $88 a b$ & $93 a$ & $78 a$ & $90 a$ & $72 \mathbf{a}$ & $25 \mathrm{ab}$ \\
\hline ARTRV/FEID & $94 a$ & $85 \mathrm{ab}$ & $87 a$ & $78 \mathrm{bc}$ & $89 a b$ & $53 b$ & $9 l a$ & $41 \mathrm{bc}$ & $22 \mathrm{ab}$ \\
\hline PIPO/FEID & $65 b$ & $76 b$ & $71 \mathrm{a}$ & $71 \mathrm{c}$ & $78 b$ & $62 \mathrm{ab}$ & $6 \mathrm{lb}$ & $33 d$ & $12 b$ \\
\hline
\end{tabular}

*Similar letters denote non-significant differences between collections at a particular temperature/moisture stress level ( $\alpha=.05)$ using Tukey's w-procedure.

in comparison to the other collections at all temperatures.

\section{Germination Response to Temperature/Water Stress}

Germination characteristics between populations varied in relation to temperature and water stress. As water stress decreased both germination amount and rate declined. A collection $\times$ temperature water stress interaction was detected for the analyses of both mean germination and CRG. Evidently, a physiological response in seed germination between water stress and temperature, which resulted in a disproportionate decline in germination percentage at $20^{\circ} \mathrm{C}$, contributed the most to the interaction sum of squares.

Interpretation of 3-way interaction means for germination (Table 4) and CRG (Table 5) indicated a similar germination response between the ARTRW/FEID and ARTRV"L"/FEID populations. Seeds collected from the ARTRV/FEID site were different than the other 2 sagebrush collections at temperature/water stress levels of $20^{\circ} \mathrm{C} / 0.9 \mathrm{MPa}$ for germination and $20^{\circ} \mathrm{C} /-0.6 \mathrm{MPa}$ for mean $\mathrm{CRG}$. Total germination of seeds imbibed in solutions of -0.6 and $-0.9 \mathrm{MPa}$ was greatest for all collections at temperatures of $15^{\circ} \mathrm{C}$ and $20^{\circ} \mathrm{C}$. Idaho fescue seeds from sagebrush sites germinated significantly better and faster over wider temperature/water stress ranges than seeds collected from the PIPO/FEID habitat type. However, as water stress declined, the differences between collections became nonsignificant.

For days to $50 \%$ germination, an interaction occurred between temperature and water stress. Again, a physiological relationship appeared to exist between incubation temperature and water stress and their combined effect upon seed germination. Population main effects in days to 50\% germination for the ARTRW/FEID, ARTRV"L"/FEID, ARTRV/FEID and PIPO/FEID collections were $10.5,11.3,11.1$, and 12.2 , respectively. Separation of main effect means for the 4 Idaho fescue populations indicated collections from sagebrush sites did not differ in days to $50 \%$ germination. Seeds collected from the PIPO/FEID habitat type, however, were significantly slower to reach $50 \%$ germination than seeds from the ARTRW/FEID and ARTRV/FEID sites.

\section{Discussion and Conclusions}

The results revealed differences in relative response to varying temperature and water stress environments among 4 Idaho fescue collections. Seeds selected from sagebrush dominated habitat types germinated better and faster over wider temperature and water stress regimes than did seeds gathered from a ponderosa pine habitat type.

These responses may be related to environmental factors under which populations of a plant species have evolved. Numerous studies have shown that germination patterns reflect the seasonal and climatic environments which naturally occur during germination (McDonough 1977, Young and Evans 1981). Selective processes have probably resulted in the development of populations, which germinate best under certain incubation regimes.

The relative order of population germination response in Idaho fescue to a wide range of temperature and water stress environments conforms to the preconceived environmental gradient that exists under natural conditions. Within the PIPO/FEID habitat type amelioration of the microclimate near the ground surface by aspect, elevation, or vegetation overstory, coupled with stressfully higher yearly precipitation amounts, conceivably reduces the need for rapid germination of a large number of seeds under a wide range of temperature and moisture stress conditions. This is not to say seeds will not germinate under other incubation regimes, but rather to imply that seeds of high elevation populations are conditioned to germinate better under the naturally cooler temperature and higher moisture environments of these sites. Seeds from the warm, dry sagebrush sites germinate fastest and most completely under a broader range of temperature and water stresses. This response may be particularly important during periods of adequate late summer or fall moisture. Because Idaho fescue seeds appear capable of germination during this time of year, sensitivity to soil moisture and temperature may be critical factors in the recruitment of new individuals into the plant community. A faster germination rate and larger germination percentage over a wider regime of environmental stresses may confer a greater chance for successful

Table 5. Three water interaction means for Coefficient of Rate of Germination (CRG) at three temperatures ( ${ }^{\circ}$ C) and three water potentials (MPa). Error mean square value from analysis of variance was 0.93 .

\begin{tabular}{|c|c|c|c|c|c|c|c|c|c|}
\hline \multirow[b]{2}{*}{ Water Stress } & \multicolumn{9}{|c|}{ CRG } \\
\hline & 0 & $\begin{array}{l}15 \\
-.6\end{array}$ & -.9 & 0 & $\begin{array}{l}20 \\
-.6\end{array}$ & -.9 & 0 & $\begin{array}{l}25 \\
-.6\end{array}$ & -.9 \\
\hline \multicolumn{10}{|l|}{ Collection } \\
\hline $\begin{array}{l}\text { ARTRW/FEID } \\
\text { ARTRV“L"/FEID } \\
\text { ARTRV/FEID } \\
\text { PIPO/FEID }\end{array}$ & $\begin{array}{l}11.2 a^{*} \\
10.8 \mathrm{a} \\
13.1 \mathrm{~b} \\
6.7 \mathrm{c}\end{array}$ & $\begin{array}{l}8.9 \mathrm{a} \\
8.9 \mathrm{a} \\
8.3 \mathrm{ab} \\
6.8 \mathrm{~b}\end{array}$ & $\begin{array}{l}5.6 \mathrm{a} \\
5.7 \mathrm{a} \\
5.6 \mathrm{a} \\
4.6 \mathrm{a}\end{array}$ & $\begin{array}{r}14.5 \mathrm{a} \\
14.5 \mathrm{a} \\
12.6 \mathrm{~b} \\
9.4 \mathrm{c}\end{array}$ & $\begin{array}{l}9.7 \mathrm{a} \\
8.9 \mathrm{a} \\
9.3 \mathrm{a} \\
6.8 \mathrm{~b}\end{array}$ & $\begin{array}{l}5.3 \mathrm{a} \\
5.1 \mathrm{a} \\
3.8 \mathrm{a} \\
4.1 \mathrm{a}\end{array}$ & $\begin{array}{l}14.4 \mathrm{a} \\
14.4 \mathrm{ab} \\
15.5 \mathrm{~b} \\
8.3 \mathrm{c}\end{array}$ & $\begin{array}{l}5.2 \mathrm{a} \\
6.3 \mathrm{a} \\
3.3 \mathrm{~b} \\
2.4 \mathrm{~b}\end{array}$ & $\begin{array}{r}2.1 \mathrm{a} \\
1.6 \mathrm{a} \\
1.2 \mathrm{a} \\
.7 \mathrm{a}\end{array}$ \\
\hline
\end{tabular}

*Similar letters denote non-significant differences between collections at a particular temperature/moisture stress level ( $\alpha=.05)$ using Tukeys-w procedure 
fall establishment. Whether or not fall or spring germination is important to the regeneration of Idaho fescue on sagebrush sites has yet to be determined.

On the basis of 1 year's analysis, it appears possible to distinguish between ecotypes within the 4 Idaho fescue collections. It is felt the pattern of germination response in seeds from the PIPO/FEID habitat type was sufficiently distinct to warrant classifying Idaho fescue on this site as a separate ecotype in comparison to plants found within the sagebrush dominated communities. This relationship is enhanced by the comparatively similar germination all collections exhibited at $10^{\circ} \mathrm{C}$ and the significant decline in response for the PIPO/FEID collection as temperature and/or water stress increased. Unlike the PIPO/FEID collection, seeds from the ARTRV/FEID site exhibited different germination characteristics in comparison to seeds from the ARTRW/FEID and ARTRV"L"/FEID sites only at a few temperature/moisture stress environments. Whether or not this represented a genetically or environmentally induced response or rcsulted from chance occurrence is hard to determine.

\section{References Cited}

Capon, B., G.L. Maxwell, and P.H. Smith. 1978. Germination responses to temperature pretreatment of seeds from ten populations of Salvia columbariae from the San Gabriel Mountains and Mojave Desert, California. Aliso 9:365-373.

Choudhuri, G.N. 1968. Effect of soil salinity on germination and survival of some steppe plants in Washington. Ecology. 49:465-471

Doescher, P.S. 1983. Phyto-edaphic relationships and ecotypic development of Festuca idahoensis in eastern Oregon habitat types of Artemisia tridentata. Ph.D. Diss., Oregon State University, Corvallis Univ. Microfilms. Ann Arbor, Mich. (Diss. Abstr. 43:2068).
Eddleman, L.E. 1979. Regeneration strategies of mixed-prairie plants. p. 684-698. In. J.R. Goodin and D.K. Northington (Eds.). Arid Land Plant Resources. International Center for Arid and Semi-arid Land Studies, Texas Tech. University, Lubbock.

Franklin, J.D., and C.T. Dyrness. 1973. Natural vegetation of Oregon and Washington. USDA, Forest Serv. Tech. Rep. PNW-8.

Lindauer, L.L., and J.A. Quinn. 1972. Germination ecology of Danthonia sericea populations. Amer. J. Bot. 59:942-951.

Maquire, J.D. 1962. Speed of germination-aid in selection and evaluation of seedling emergence and vigor. Crop Sci. 2:176-177.

McDonough, W.T. 1977. Seed physiology. p. 154-184. In: R.E. Sosebee, editor, Rangeland Plant Physiology. Society for Range Management. Denver, Colo.

Michel, B.E., M.R. Kaufmann, 1983. The osmotic potential of polyethylene glycol 6000. Plant Physiology. 51:914-916.

Sokal, R.R., and F.J. Rohlf. 1969. Biometry. W.H. Freeman and Company San Francisco.

Steel, R.G.D., and J.H. Torrie. 1980. Principles and procedures of statistics. McGraw-Hill Book Company, Inc., New York.

Stocker, R.K. 1975. A transplant study of high and low altitude populations of eight perennial grasses and forbs. Ph.D. Diss., Washington State University, Pullman. Univ. Microfilms. Ann Arbor, Mich. Diss. Abstr. 36:3749-3750.

Turesson, G. 1922. The species and the variety as ecological units. Hereditus. 3:100-113

Winward, A.H. 1970. Taxonomic and ecological relationships of the big sagebrush complex in Idaho. Ph.D. Diss., University of Idaho, Moscow. Univ. Microfilms. Ann Arbor, Mich. Diss. Abstr. 31:3791-3792.

Workman, J.P., and N.E. West. 1967. Germination of Eurotia lanata in relation to temperature and salinity. Ecology 48:659-661.

Young, J.A., and R.A. Evans, R.E. Eckert, Jr., and R.D. Ensing. 1981. Germination-temperature profiles for Idaho and sheep fescue and Canby Bluegrass. Agron. J. 73:716-720.

\title{
New!
}

\section{Vegetation Changes on Western Rangelands}

\author{
by Farrel A. Branson
}

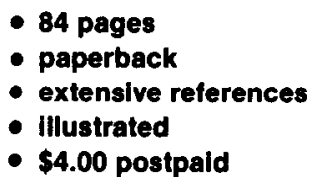

This book provides a comprehensive source of information on vegetation changes that have occurred on western rangelands during the past 100 years. It is illustrated with maps and photographs. The comments of one reviewer of the manuscript are as follows:

"It is a very good source of information on vegetation types for students as well as range professionals. It would be a good text for range community courses and portions could be used for selected assignments in other range courses. It brings together the primary references and provides so much more information to date than our present texts. I strongly believe that it will be a well-referred source. It would also improve the image of the range profession as one that is tremendously knowledgeable about the resources it manages. Branson's style of writing is good. It is straight forward and uncomplicated."Dr. M. Hironaka, University of Idaho, Moscow, Idaho.

Range professors and students, private and public range managers, soil conservationists, wildlife managers, and others will find the book a valuable contribution to their libraries. Available from the Society for Range Management 2760 W. Fifth Ave, Denver, CO 80204. 